Serang, Y., \& Laili, V. (2021). Measuring the Antioxidant Effect of Limnocharis Flava on Malondialdehyde Activities in Livers of Aloxan-Induced Diabetic Rats. JURNAL INFO KESEHATAN, 19(2), 181-186. https://doi.org/10.31965/infokes.Vol19/ss2.534

Jurnal Info Kesehatan

Vol. 19, No. 2. December 2021, pp. 181-186

P-ISSN 0216-504X, E-ISSN 2620-536X

DOI: 10.31965/infokes. Vol19Iss2.534

Journal homepage:http://jurnal.poltekeskupang.ac.id/index.php/infokes

\title{
Measuring the Antioxidant Effect of Limnocharis Flava on Malondialdehyde Activities in Livers of Alloxan-induced Diabetic Rats
}

\author{
Yithro Serang $^{12^{*}}$, Virda Laili $^{1 \mathrm{~b}}$ \\ ${ }^{1}$ Department of Pharmacy, Nusaputera College of Pharmacy, Semarang, Central Java, \\ Indonesia. \\ ${ }^{a}$ Email address: ithoserang@ gmail.com \\ ${ }^{\text {b }}$ Email address: virdalaillisholia76512@gmail.com
}

Received: 2 June $2021 \quad$ Revised: 6 December 2021

Accepted: 17 December 2021

\begin{abstract}
Antioxidants are substances counteracting the effects of free radicals. Antioxidants are formed in several forms, encompassing vitamins, minerals, and phytochemicals. Genjer or yellow velvet leaves (Limnocharis Flava) is an aquatic plant potentially beneficial alternative to natural antioxidants. This study aims to measure the antioxidant effect from the yellow velvetleaf ethanol extract on malondialdehyde (MDA) activities in livers of diabetic rats (Rattus novergicus) induced by alloxan in three different doses. The tested animals were randomly divided into five groups comprising six white rats previously induced with alloxan by intraperitoneal injection. Group 1 was the negative control provided $0.5 \% \mathrm{CMC}$ Na while group 2 was a positive control administered $0.45 \mathrm{mg}$ glibenclamide. On the other hand, groups 3,4 , and 5 were the experimental groups that provided the extract of yellow velvetleaf as many as 32.5 $\mathrm{mg} / \mathrm{kg}$ body weight (BW) ethanol, $65 \mathrm{mg} / \mathrm{kg} \mathrm{BW}$ ethanol extract, and $130 \mathrm{mg} / \mathrm{kg} \mathrm{BW}$, respectively. Furthermore, the extracts were administered once on the 7th, 14th, and 21 st days; the parameters observed were MDA activities in the rats' livers. The Thiobarbituric Acid Reactive Substances (TBARs) method was then employed to investigate these actions. The oneway ANOVA was administered to examine the acquired data from the examination, followed by a post hoc test. The average points of the MDA level from group 1 to group 5 were 10.780 .33 , $3.71+0.19,7.25+0.26,5.76+0.25$, and $4.01+0.22$, correspondingly, according to the results. The one-way ANOVA test revealed that MDA levels in each test group were significantly different ( $\mathrm{p}$ 0.05). Based on these findings, it may be concluded that feeding ethanol extract from yellow velvet leaves to diabetic rats reduces MDA levels in their livers, therefore preserving cells from harm.
\end{abstract}

Keywords: Yellow Velvet Leaves, The Liver's MDA Level, Antioxidant Activities, Limnocharis Flava.

*Corresponding Author:

Yithro Serang

Department of Pharmacy, Nusaputera College of Pharmacy, Semarang, Central Java, Indonesia.

Email: ithoserang@gmail.com

CThe Author(s) 2021. This article is distributed under the terms of the Creative Commons Attribution 4.0 International License (http://creativecommons.org/licenses/by/4.0/), which permits unrestricted use, distribution, and reproduction in any medium, provided you give appropriate credit to the original author(s) and the source, provide a link to the Creative Commons license, and indicate if changes were made. The Creative Commons Public Domain Dedication waiver (http://creativecommons.org/publicdomain/zero/1.0/) applies to the data made available in this article, unless otherwise stated. 


\section{INTRODUCTION}

Metabolic disease such as diabetes mellitus (DM) is a disease characterized by a high blood glucose level (hyperglycemia) due to insulin work disruption. This kind of disorder is affected by several factors and indicated by symptoms such as hyperglycemia and metabolism disorders of carbohydrates, fat, and protein. A lack of insulin secretion, insulin actions, and glucose transporter results in the development of such a disease (Maulana, 2009).

Multiple organ failures in chronic hyperglycemic diabetes are associated with long-term damage to kidneys, nerves, blood vessels, eyes, and the heart (Prawitasari, 2019). The failure of the pancreas to secrete insulin, which transforms carbohydrates, fats, and proteins into energy, causes this damage. Insulin is the hormone in charge of regulating blood sugar levels (American Dental Association, 2010; American Dental Association, 2011; American Dental Association, 2015).

One of the most reactive radicals is the hydroxyl radical. The lipid membrane will react with this radical to generate Malondialdehyde (MDA) compounds if it comes into contact with it (Oyenihi, et al., 2015). Furthermore, the hydroxyl radical can permeate through cell membranes and is exceedingly hazardous. Malondialdehyde is a lipid peroxidation end product that is employed to measure oxidative stress and the risk of problems in diabetes mellitus. Molecular changes in diverse tissues are the result of oxidative stress, and this state produces an imbalance between the increased generation of free radicals and the formation of protective (endogenous) antioxidants (Widyawati, 2016). As a result of this imbalance, oxidative damage occurs, raising the risk of complications in diabetes mellitus (Mahreen, et al., 2010).

The liver is an organ which is responsible for the gluconeogenesis and glycogenesis processes (Rajendiran, et al., 2018). When insulin resistance occurs, both processes are disrupted and cause hyperglycemia. Hyperglycemia triggers reactive oxygen species (ROS) to re-form (Aprilia, et al., 2018). One of the prior targets of ROS is lipid; when hepatic insulin resistance occurs, numerous lipids accumulate in hepatocyte cells. The hepatocellular lipids acquiring approximately 5.5\% are considered nonalcoholic fatty liver (NAFL), a manifestation of DM (Szendroedi, et al., 2012).ROS is able to attack polyunsaturated fatty acids (PUFA), hence, the final product is generated in the form of reactive aldehyde compounds such as Malondialdehyde (MDA) (Tiwari, et al., 2013). Antioxidants can prohibit MDA formation. The antioxidant capacity of DM is reduced, necessitating the use of external antioxidants (Marra, et al., 2002). According to Maisuthisakul, et al., (2008), L. Flava contains phenolics of up to $5.4 \mathrm{mg} \mathrm{GAE} / \mathrm{g}$ dry weight and flavonoids of up to $3.7 \mathrm{mg} \mathrm{RE} / \mathrm{g}$ dry weight in Thailand. Yellow velvetleaf (L. Flava) is an aquatic plant that has the potential to be one of the natural antioxidants that may successfully combat free radicals.

The objective of this study is to investigate the effects of the ethanol extract from yellow velvetleaves upon MDA activities in the livers of diabetic rats induced by alloxan, hence scientific information about an alternative natural antioxidant in diabetes mellitus therapy.

\section{RESEARCH METHOD}

This experimental laboratory research employed diabetic white rats. The rats were the 2-3 months albino lab rats weighing 200-300 grams, randomly divided into five 
groups. Each group was comprised of 6 rats. The positive control group was provided $0.45 \mathrm{mg}$ glibenclamide. The negative control group was $0.5 \% \mathrm{CMC} \mathrm{Na}$, and three testing groups were provided $32.5 \mathrm{mg} / \mathrm{kg} \mathrm{BW} / \mathrm{kg}, 65 \mathrm{mg} / \mathrm{kg} \mathrm{BW} 130 \mathrm{mg} / \mathrm{kg} \mathrm{BW}$ of yellow velvetleaf extracts, respectively. Previously, all rats were provided alloxan by intraperitoneal injection. Each group was supplied treatment according to their respective groups on the 7 th, 14 th, and 21 st weeks. Furthermore, the antioxidant activity tests of MDA activities were performed employing the Thiobarbituric Acid Reactive Substances (TBARs) method. The data were then collected and analyzed statistically, administering the one-way ANOVA.

The tools utilized in this research were syringes (Terumo), $500 \mathrm{ml}$ beaker glass (Pyrex), analytical scales (Mettlertoledo), $10 \mathrm{ml}$ and $25 \mathrm{ml}$ measuring flasks (Pyrex), glucometers (easy touch), porcelain dishes (Haldenwanger), mortars and stampers (Haldenwanger), stirring rods (pyrex), a rotary evaporator (Scilogex), test tubes (Pyrex), TLC vessels (Macherey Nagel), TLC plate silica gel 60 F254 (Merck), an oven (Cosmos), measuring cups (Pyrex), glass pipettes (Pyrex), and spectrophotometers (Shimadzu).

The yellow velvetleaf powder, which included $10 \%$ moisture, weighed 500 grams. The powder was then placed in a closed vessel and macerated for four days in 2 liters of $70 \%$ ethanol, rotating it back and forth. After that, the sample was concentrated in a rotary evaporator at $400^{\circ} \mathrm{C}$ until a thick extract was obtained.

There are 30 white labs in all. The rats were separated into five groups, each weighing 200 grams. On the 7th, 14th, and 28th days, the experimental animals were provided the following treatments: group 1 received $0.5 \mathrm{ml} \mathrm{Na} C M C$ suspension as a placebo, group 2 received glibenclamide $0.45 \mathrm{mg}$ as a positive control, and groups 3,4 , and 5 obtained yellow velvetleaf extracts at doses of 32.5 per $\mathrm{kg} / \mathrm{BW}, 65 \mathrm{per} \mathrm{kg} / \mathrm{BW}$, and 130 per $\mathrm{kg} / \mathrm{BW}$, respectively. Afterward, all animals were provided $120 \mathrm{mg} / \mathrm{kg} \mathrm{BW}$ alloxan injections to induce diabetes.

All test animals were decapitated, and their livers were obtained. The livers were then washed with a physiological $0.9 \% \mathrm{NaCl}$ solution and chopped under cold conditions. The resulting homogenate was centrifuged at $4000 \mathrm{rpm}$ for 10 minutes until a clear supernatant was collected. The clear supernatant was employed for the MDA testing. In the next process, as many as $0.75 \mathrm{ml} \mathrm{H} 2 \mathrm{PO} 4$ was placed in the polypropylene tube containing thiobarbituric acid TBA, and $0.05 \mathrm{ml}$ liver sample and $0.45 \mathrm{ml}$ distilled water were administered. This mixture was mixed for 2 minutes before being heated in a water bath at $1000 \mathrm{C}$ for 60 minutes and then cooled in an ice bath. The solution was then transferred from the ice bath to Sep-Park 18, where the MDA values were measured using a spectrophotometer at $532 \mathrm{~nm}$.

Five series of MDA standard concentration were produced $(0,0.375,0.75,1.5$ and 3 ) and the absorbance was calculated by employing a spectrophotometer $(0.021,0.037$, $0.068,0.151$, and 0.242). Based on the regression analysis, the equation $\mathrm{Y}=-0.1479+$ $12.45 \mathrm{x}$ was obtained. The absorbancy of the MDA sample was then assessed and substituted in the equation above to formulate MDA levels in $\mathrm{nmol} / \mathrm{g}$. This research has received ethical permission from the Medical/Health Research Bioethics Commission, Faculty of Health, Sultan Agung Islamic University Semarang No. 298/IX/2020/Bioethical Commission. 


\section{RESULTS AND DISCUSSION}

Based on the regression analysis of MDA levels in diabetic rats induced by alloxan, the levels of treatment groups were presented in table 1 . These data were then analyzed statistically by employing the one-way ANOVA to identify the differences among the treatment groups.

Table 1.The decreased MDA levels in the treatment groups to the control groups

\begin{tabular}{lrr}
\hline Groups & Average \pm SD $(\mathbf{n m o l} / \mathbf{g})$ & $\boldsymbol{p}$-value \\
\hline Negative control & $10.78 \pm 0.33$ & \\
Positive control & $3.71 \pm 0.19$ & \\
$3.25 \mathrm{mg} / \mathrm{kg} \mathrm{bw}$ & $7.25 \pm 0.26$ & 0.05 \\
$65 \mathrm{mg} / \mathrm{kg} \mathrm{bw}$ & $5.76 \pm 0.25$ & \\
$130 \mathrm{mg} / \mathrm{kg} \mathrm{bw}$ & $4.01 \pm 0.22$ & \\
\hline
\end{tabular}

The parameter malondialdehyde (MDA) is employed to measure the extent of tissue damage induced by free radicals. MDA enzyme levels in liver homogenates that had been treated with the extract for 21 days were tested to examine the capacity of the yellow velvetleaf ethanol extract to increase antioxidant activities. Alloxan was utilized as the free radical agent in this investigation to generate oxidative damage to the pancreas of rats. Alloxan injections of $120-150 \mathrm{mg} / \mathrm{kg}$ BW resulted in hyperglycemic rats. This chemical can cause diabetes mellitus in experimental animals if they have diabetes mellitus type I symptoms comparable to those seen in people (Yuriska, 2009). Furthermore, hyperglycemia promotes the generation of free radicals.

On the other hand, glibenclamide, employed in the positive control, increases the release of insulin from the pancreas and causes glucose to enter the muscles, which decreases the glucose level in the blood. Glibenclamide also created the balance in the pancreas and created the defense against endogenous enzymes able to neutralize free radicals, as evidenced by the decreased levels of MDA. Flavonoids, alkaloids, and saponins are compounds considered to possess antioxidant activities. Antioxidants in flavonoids occur because the hydroxyl group is attached to the aromatic carbon ring. Hence, it is able to capture free radicals resulting from the reaction of fat peroxidation. Moreover, flavonoid compounds release one hydrogen atom to stabilize the proxy fat radical (Hamid, 2010). Giorgio, (2000) asserted that the ability of flavonoids has been extensively studied recently, and it is identified that flavonoids can change or reduce free radicals, which is functioning as anti-free radicals.

The liver plays a significant role in the detoxification process. Thus, it is necessary to measure MDA levels to determine oxidative damage. The liver desaturated fatty acids to provide unsaturated fatty acids, which are sensitive to free radical compounds (Zacharia, et al., 2012). Given the yellow velvetleaf extracts, the treatment groups possessed significantly lower MDA levels than the negative control provided $0.5 \%$ (K-) CMC NA. The high levels of MDA in the negative control indicate that there has been oxidative stress decreasing antioxidant enzyme activities. The high levels of MDA in the negative control create an imbalance between oxidative compounds and endogenous antioxidant components, which affects oxidative stress and reduces antioxidant activities. Therefore, such a condition leads to liver cell damage which diminishes the liver's ability to neutralize the harmful compounds. There was a significant difference in the decreased MDA levels in the treatment groups compared to the negative control $(\mathrm{p}<0.05)$. It indicates that the yellow velvetleaf extract is able to inhibit MDA formation in the liver, hence lowering the MDA level. This fact is also in accordance with the research conducted by Lee, et al., (2011), which revealed that 
providing the ethanol extract of yellow velvetleaf to rats can reduce MDA levels in the liver and increase the endogenous antioxidant enzyme SOD (Superoxide dismutase).

Thus, there was no significant difference in lowered liver MDA levels between all treatment groups and the positive control ( $p>0.05)$ based on the Post Hoc LSD test findings and the Tukey's test. After 21 days of treatment, the ethanol extract of yellow velvetleaf (Limnocharis Flava) and glibenclamide administered to the positive control both reduced MDA levels in the liver.

\section{CONCLUSION}

The researchers discovered that feeding the ethanol extract of yellow velvet leaves (Limnocharis Flava) to alloxan-induced diabetic mice reduces liver MDA levels, with the highest beneficial dose being $130 \mathrm{mg} / \mathrm{kg}$ BW $(4.01 \pm 0.22 \mathrm{nmol} / \mathrm{g})$. The decrease in MDA levels is a measure of antioxidant activity. Therefore the lower the MDA level, the higher the antioxidant activity.

\section{REFERENCES}

American Diabetes Association (2010). Diagnosis and classification of diabetes mellitus. Diabetes care, 33 Suppl 1(Suppl 1), S62-S69. doi: https://doi.org/10.2337/dc10-S062

American Diabetes Association. (2011). Diagnosis and classification of diabetes mellitus. Diabetes care, 34 Suppl l(Suppl 1), S62-S69. doi: https://doi.org/10.2337/dc11-S062

American Diabetes Association. (2015). (2) Classification and diagnosis of diabetes. Diabetes Care. 38 Suppl, S8-S16. doi: https://doi.org/10.2337/dc15-S005

Andersen, O. M., \& Markham, K. R. (2005). Flavonoids: chemistry, biochemistry and applications. Florida: CRC press. doi: https://doi.org/10.1201/9781420039443

Aprilia, N., Ariyani, A. D., \& Hidayatin, N. (2018). Pengaruh Rebusan Buncis terhadap Kadar Gula Darah pada Penderita Diabetes Melitus di Kelurahan Tukangkayu Wilayah Kerja Puskesmas Sobo Banyuwangi. Jurnal Kesehatan, 11(2), 122-135. doi: https://doi.org/10.24252/kesehatan.v11i2.6454

Giorgio, P. (2000). Flavonoid an antioxidant. Journal National Product, 63(1), 10351045.

Hamid, A. A., Aiyelaagbe, O. O., Usman, L. A., Ameen, O. M., \& Lawal, A. (2010). Antioxidants: Its medicinal and pharmacological applications. African Journal of pure and applied chemistry, 4(8), 142-151.

Lee, S. J., Lee, J. H., Lee, H. H., Lee, S., Kim, S. H., Chun, T., \& Imm, J. Y. (2011). Effect of mung bean ethanol extract on pro-inflammtory cytokines in LPS stimulated macrophages. Food Science and Biotechnology, 20(2), 519-524. doi: https://doi.org/10.1007/s10068-011-0072-z

Mahreen, R., Mohsin, M., Nasreen, Z., Siraj, M., \& Ishaq, M. (2010). Significantly increased levels of serum malonaldehyde in type 2 diabetics with myocardial infarction. International journal of diabetes in developing countries, 30(1), 49-51.

Maisuthisakul, P., Pasuk, S., \& Ritthiruangdej, P. (2008). Relationship between antioxidant properties and chemical composition of some Thai plants. Journal of Food Composition and Analysis, 21(3), 229-240. doi: https://doi.org/10.1016/j.jfca.2007.11.005

Marra, G., Cotroneo, P., Pitocco, D., Manto, A., Di Leo, M. A., Ruotolo, V., ... \& Santini, S. A. (2002). Early increase of oxidative stress and reduced antioxidant 
defenses in patients with uncomplicated type 1 diabetes: a case for gender difference. Diabetes care, 25(2), 370-375. doi: https://doi.org/10.2337/diacare.25.2.370

Maulana, H. D. (2009). Promosi Kesehatan. Jakarta: EGC.

Oyenihi, A. B., Ayeleso, A. O., Mukwevho, E., \& Masola, B. (2015). Antioxidant strategies in the management of diabetic neuropathy. Biomed Res Int, Article ID 515042 . doi: https://doi.org/10.1155/2015/515042

Prawitasari, D. S. (2019). Diabetes Melitus dan Antioksidan. KELUWIH: Jurnal Kesehatan dan Kedokteran, 1(1), 48-52. doi: https://doi.org/10.24123/kesdok.V1i1.2496

Rajendiran, D., Packirisamy, S., \& Gunasekaran, K. (2018). A Review On Role Of Antioxidants in Diabetes. Asian Journal of Pharmaceutical and Clinical Research, 11(2), 48-53. doi: https://doi.org/10.22159/ajpcr.2018.v11i2.23241

Szendroedi, J., Phielix, E., \& Roden, M. (2012). The role of mitochondria in insulin resistance and type 2 diabetes mellitus. Nature Reviews Endocrinology, 8(2), 92103. doi: https://doi.org/10.1038/nrendo.2011.138

Tiwari, B. K., Pandey, K. B., Abidi, A. B., \& Rizvi, S. I. (2013). Markers of oxidative stress during diabetes mellitus. Journal of Biomarkers, Article ID 378790. doi: https://doi.org/10.1155/2013/378790

Widyawati, P. S. (2016). Determination of antioxidant capacity in Pluchea indica Less leaves extract and its fractions. International Journal of Pharmacy and Pharmaceutical Sciences, 8(9), 32-36. doi: https://doi.org/10.22159/ijpps.2016v8i9.11410

Yuriska, A. (2009). Efek aloksan terhadap kadar glukosa darah tikus winstar. Skripsi. Fakultas Kedokteran, Universitas Diponegoro-Semarang.

Zakaria, F. R., Prangdimurti, E., Puspawati, G. K. D., Thahir, R., \& Suismono, S. (2011). Diet Berbasis Sorgum (Sorghum bicolor L Moench) Memperbaiki Proliferasi Limfosit Limfa dan Kapasitas Antioksidan Hati Tikus. Jurnal Pangan, 20(3), 209-222. doi: https://doi.org/10.33964/jp.v20i3.155 